IRSTI 03.41.91

\author{
Kitov E. ${ }^{1}$, Bexeitov G. ${ }^{2}$, Ospanov E. ${ }^{3}$, Satayeva B. ${ }^{4}$ \\ ${ }^{1}$ Researcher at the Center for Physical Anthropology, \\ Institute of Ethnology and Anthropology RAS, Russian, Moscow, e-mail: kadet_eg@mail.ru \\ ${ }^{2}$ Associate Professor, e-mail: bek ok@mail.ru \\ 3e-mail: yerbolat_27@mail.ru \\ ${ }^{4}$ Junior Researcher, e-mail: botakozsatayeva@gmail.com \\ Al-Farabi Kazakh National University, Kazakhstan, Almaty
}

\title{
ANTHROPOLOGICAL DATA FROM «RAKHAT» GRAZZLE (Almaty region)
}

\begin{abstract}
In the article was described the geographical location of the settlement area and unique features of the region Rakhat. During 1994-2005 settlement area was carried out archaeological excavation of the joint Kazakh-American expedition under the leadership by K.M. Baipakov, F.P. Grigoriev, K. Chang. There were done expertise and description to the archaeological excavation of monuments which located in settlement area of Rakhat in the Institute of Archaeology named after A.Kh. Margulan in 2004. As well as, in the Upper Paleolithic place the various levels of mineral excavation, exploration work were characterized fully by the leadership of O.N. Artyukova in the location of Rakhat in 2006-2007. The work of the members of the archaeological expedition was analyzed under the leadership of B.Nurmaganbetov of the memorial museum «Esik» in 20112012. Along with archaeological excavation, new research methods of the scientists of Natural sciences were utilized, in the international scientific -research laboratory "Geoarcheology» of al-Farabi university was made expert examination of the results and the current state and future of archaeological excavations which carried out in the framework of the State Program «The people in the flow of history» in the location of Rakhat by the leadership of G.T. Bexeitov in 2015. In addition, there were paid more attention to the palynological, geological and geomorphological characteristics of the region and through carrying out snip excavations in the upper paleolithic nomad camp and mounds were done expertise to found stone artifacts. The paleoanthropological examination was considered to bone skeletons of Rakhat mound.
\end{abstract}

Key words: Kurgan, skull, anthropology, skeleton, pathology.

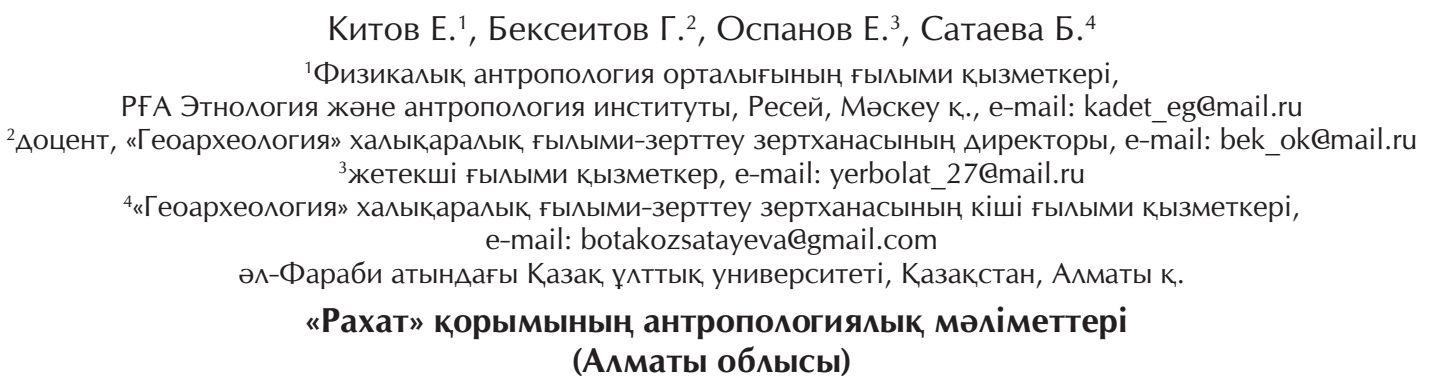

Мақалада Рахат елді-мекенінің географиялық орналасу шекарасы мен өңірдің өзіне ғана тән ерекшеліктері сипатта^ды. Елді-мекенді 1994-2005 жылдары К.М. Байпақов, Ф.П. Григорьев, К. Чанг жетекшілік еткен, біріккен «Қазақ-Американ» экспедициясының археологиялық қазба жұмыстары қамтылған. 2004 жылы Ә.Х. Марғұлан атындағы Археология Институтының Рахат елді-мекеніндегі ескерткіштерге жасаған археологиялық барлау қазба жұмыстарына сипаттама беріліп, сараптама жасалды. Сонымен қатар, Рахат елАі-мекенінде орналасқан, жоғары палеолиттік тұрағында 2006-2007 жылдары О.А. Артюхованың жетекшілігімен жүргізілген, түрлі деңгейдегі қазба, барлау жұмыстары толыққанды сипатталды. Сондай-ақ, 2011-2012 жы^дары 
«Есік» тарихи-қорық мұражайының Б. Нұрмағанбетұлы жетекшілік жасаған, археологиялық, экспедициясы мүшелерінің жұмыстары сараланды. Археологиялық қазба жұмыстарымен қатар, жаратылыстану ғылымдарының жаңа ғылыми-зерттеу әдіс-тәсілдерін пайдаланып, 2015 жылы Рахат елді-мекенінде Ғ.Т. Бексеитов басшылық жасап отырған, әл-Фараби атындағы ҚазҰУ-дың жанындағы «Геоархеология» халықаралық ғылыми-зерттеу зертханасы «Халық тарих толқынында» атты мемлекеттік бағдарламасы шеңберінде жүргізген археологиялық қазба жұмыстарының (Палеолит-Ерте темір дәуірі) нәтижелеріне және мекеннің қазіргі жағдайы мен болашағына сипаттама жасалды. Сонымен қатар, Рахат қорғандарынан шыққан сүйек қаңқаларына жасаған палеоантропологиямық, сараптама жұмысы қарастырылды.

Түйін сөздер: Қорған, бас сүйек, антропология, қаңқа, патология.

\author{
Китов Е. ${ }^{1}$, Бексеитов Г. ${ }^{2}$, Оспанов Е. ${ }^{3}$, Сатаева Б. ${ }^{4}$ \\ ${ }^{1}$ научный сотрудник Центра физической антропологии, \\ Институт этнологии и антропологии РАН, Россия, г. Москва, e-mail: kadet_eg@mail.ru \\ ${ }^{2}$ Аоцент, Международная научно-исследовательская лаборатория \\ «Геоархеология», e-mail: bek ok@mail.ru \\ ${ }^{3}$ ведущий специалист, e-mail: yerbolat_27@mail.ru \\ ${ }^{4}$ младший научный сотрудник, Международная научно-исследовательская лаборатория \\ «Геоархеология», e-mail: botakozsatayeva@gmail.com \\ Казахский национальный университет имени аль-Фараби, Казахстан, г. Алматы
}

\title{
Антропологические данные с могимьника «Рахат» (Алматинская область)
}

\begin{abstract}
В статье описывается географическое расположение села Рахат и уникальные особенности самого региона. В 1994-2005 гг. под руководством К.М. Байпакова, Ф.П. Григорьева, К. Чанг совместная казахско-американская экспедиция проводила в местности Рахат археологические раскопки на городище «Рахат». В 2004 году археологическая экспедиция Института археологии имени А.Х. Маргулана проводила здесь археологические разведывательные работы и дала свой анализ по данным памятникам. Кроме того, в 2006-2007 году на позднепалеолитической стоянке Рахат были проведены полноценные археологические разведывательные и раскопочные работы под руководством О.А. Артюховой. В статье изложены работы археологической экспедиции, проводившейся в данной местности Государственным историко-культурным заповедникоммузеем «Иссык» под руководством Б. Нурмагамбетова. В Аополнение к археологическим раскопкам, используя новые методы научных исследований в области естественных наук, в 2015 году под руководством Г.Т. Бексеитова Международная научно-исследовательская лаборатория «Геоархеология» в КазНУ им. аль-Фараби по государственной программе «Народ в потоке истории» проводила на памятниках «Рахат» (Палеолит-РЖВ) археологические исследования и раскопки. Были проведены палеоантропологические исследования найденых матералов.
\end{abstract}

Кмючевые слова: Курган, череп, антропология, скелет, патология.

\section{Introduction}

Gaining independence of our republic and becoming a sovereign state, it still allows us to study our history in a new way. In this regard, many research works have been carried out on the historic sites worthy of national interest in the history of our country, and mystery pages of our history are being discovered. Today the country's rapid development requires to study deeply the historical truth, own way of the history of the nation needs to write a new data based on artifacts found during archaeological excavations.

Our people have gone through many difficult times on this path. It is obvious that from the ancient times to the present day the history of the Kazakh people, which has not survived, has not lost its continuity. Ceramic, bow spearhead, skeletal remains and rock artifacts are particularly important in determining the age of historical sites, because the period can be determined depending on their structure of creation, the nature of the species, the specificity of preservation. One of the most intricate and unexplored forms of research at that time are the monuments which located near the settlement area of Rakhat (the Enbekshikazakh district, Almaty region).

Rakhat monuments are a historically significant site located at the foot of the mountains which is 5 kilometers away from southern burial grounds «Esik», Enbekshikazakh district, Rakhat rural district of Almaty region. At the moment, civilized nations and nationalities are primarily interested in their past and present. 
It demonstrates the importance of the true history of our people, through the research and deep scientific expertise.

Geographical coordinates of the village: N: $43^{\circ} 20.250$ '; E: $077^{\circ}$ 22.614. The total area of monument is occupied 88.7 hectares. It is one of the most historically significant objects of the $5 \mathrm{~km}$ square of the Issyk-Talgar highway, on the southern slope of the Esik monastery in Enbekshikazakh district of Almaty region (Martynov, 2005).

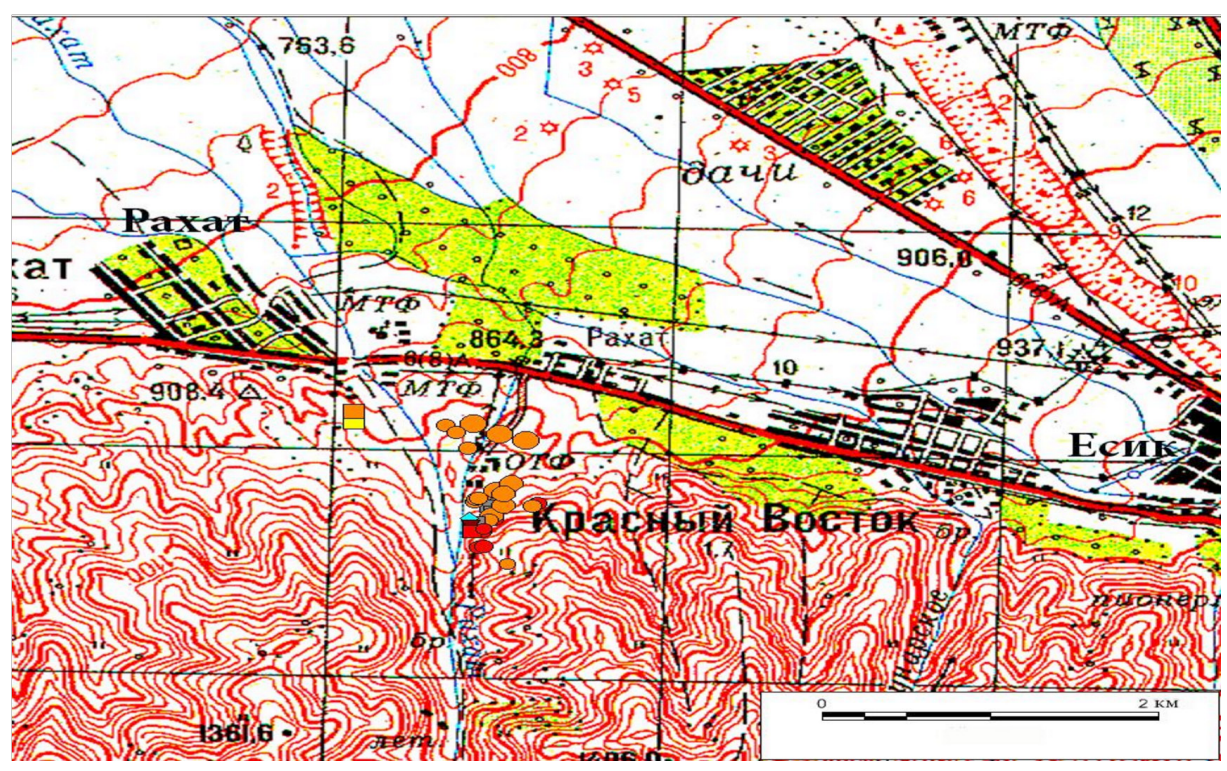

Figure 1 - Rakhat. Topographical location of mounds

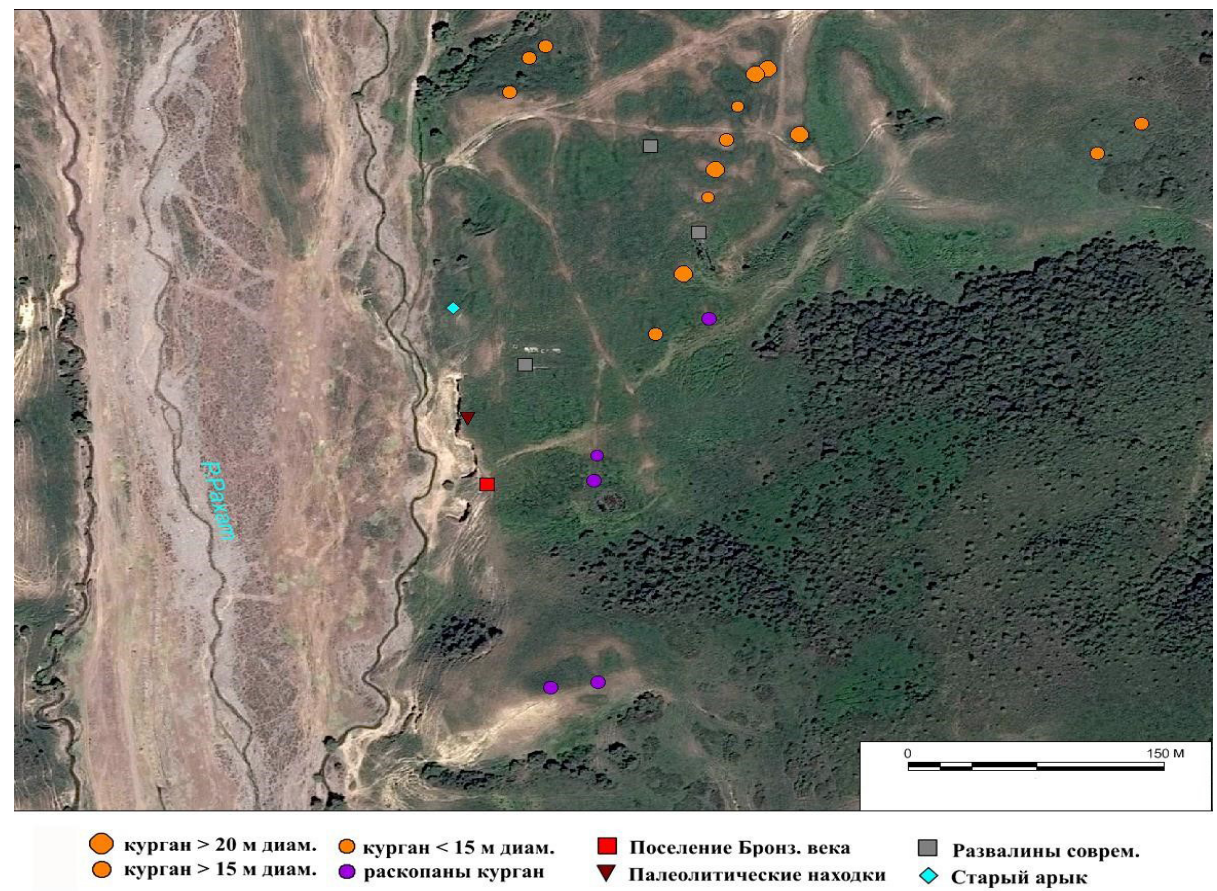

Figure 2 - Rakhat. Location of mounds in the area 
In its turn, exploration and excavations were carried out in the organization of archaeological research of settlement. In the monuments of Rakhat were carried out effective scientific-research works by leaders of archaeological excavation of the joint Kazakh-American expedition: K.M. Baipakov, F.P. Grigoriev, K. Chang. (Baipakov, 2009).

During the expedition of settlement area, characteristic of the Sak-Uysun stages as dwelling shelters, semi-cellars and dwellings made of semibricks were dug, collected ceramic remains and artifacts and conducted examination in the foreign scientific-research centers. As a result, through using the scientific- research methods which inherent to the natural sciences, the prevalence of fruitful result of archeological excavations of the joint expedition in the information society has become important.

There was conducted archeological excavation of 5 mounds in the location of Rakhat by the staff of Institute of Archeology named after A.Kh. Margulan in 2004. As well as, the monuments and settlements of the location Rakhat were not included only in the region of Zhetysu, also in a number of important complexes of Central Asia. Sak, Uysun, Huns, Turks people, other ancient and subsequent tribes lived in the parts of the Ile-Alatau can take an important role in the area of Jetysu (Nurmukhanbetov, 2001: 54-56).

The first efficient excavations work in Paleolithic nomad camp of the location Rakhat was carried out in 2006-2007. Expedition was led by O.A. Artyukhova, as a result found artifacts gave opportunities to determine the age of nomad camps. It is possible to say that the historical roots of the settlement is very deep, because it is the evidence that magnificent monuments and nomad camps of the Stone, Bronze, Iron ages were settled here (Nurmukhanbetov, 2012: 88-92).

The scientific staff of the «Esik» historicalreserve museum had organized archaeological exploration and excavations in the Rakhat settlement that led by B.Nurmukhanbetuly between 20112012 , consequently scientific study suggests that the history of this region had started from the Stone Age, by digging the mounds inherent to Sak, Uysun, Huns and Turks an invaluable contribution was added to the history of Kazakh (Nurmukhanbetov, v.d. 2005: 17-18).

On October 15, 2015 the international scientificresearch laboratory "Geoarcheology» of Kazakh National university in the framework of the State Program «The people in the flow of history» was held a considerable archaeological excavations in the nomadic camps and mounds inherent to the period of Sak-uysun, near the village Rakhat in the Upper Paleolithic nomadic camp «Rakhat». The connection of archaeological research with Natural science as Chemistry, Physics, and Biology, there were fulfilled works by using new methods of scientific study as geomorphology, geology, palynology, trasology and dendrology.

In autumn and spring 2017 archeological exploration was held by managing G.T. Bexeitov Can.His.Sc., associate professor, the director of the international scientific -research laboratory «Geoarcheology» of KAZNU. As a result, it is planned to carry out excavations at the monuments located near Rakhat in 2018.

\section{On the basis of paleoanthropological data}

Work with anthropological material was carried out in the research laboratory of paleoanthropological study of Kazakhstan at the Institute of Archeology named after A.Kh. Margulan in 2016.

The preservation of anthropological material is satisfactory. Determination of sex and age were conducted by standard methods M.M. Gerasimov (1955), V.P. Alekseev, G.F. Debets (1964), V.I. Pashkova (1963), V.P. Alekseev (1966), Philip Walker and others (1988). A correlation was recorded between the data, on the one hand, the tooth age, and, on the other, the skelet. Measurement and description of osteological characteristics were carried out using standard anthropological and forensic methods (Alekseev, Debets, 1964; Alekseev, 1966; Buzhilova, 1998; Dobryak, 1960; Pashkova, 1963). For the evaluation of the sign values were utilized the absolute value clauses compiled by V.V. Bunak and A.G. Tikhonov. To assess the categories of indicators and the shape of bone sections were used data of V.P. Alekseev (Buzhilova, 1998).

Rakhat burial ground.

The remains of four individuals from the burials of three mounds were investigated. The preservation of anthropological materials is satisfactory. Sex and age determinations are presented in Table 1.

Mound №1

It is represented by a skull of poor preservation. Restoration was not applied. The facial section is represented by the maxilla and the nasal region. The brainpan is visually of medium length, mediumhigh, brachicranal. The facial section has mediumwide and high, with high and medium-wide nasal bones with an average protrusion of the nose. Nasal bones are long. The similar features of combination are characteristic of the Sak- Uysun groups of the Zhetisu (Figure 5). 
Table 1 - sex-age determinations of individuals from the burial ground of Rakhat (E.P. Kitov)

\begin{tabular}{|c|c|c|}
\hline Mound / burial & Sex & Age (year) \\
\hline Mound 1 & Male & $35-45$ \\
\hline Mound 2 & Female & $18-25$ \\
\hline Mound 3 b.1 low. & Male & $40-45$ \\
\hline Mound 3 b.1 upp. & Male & $25-35$ \\
\hline
\end{tabular}

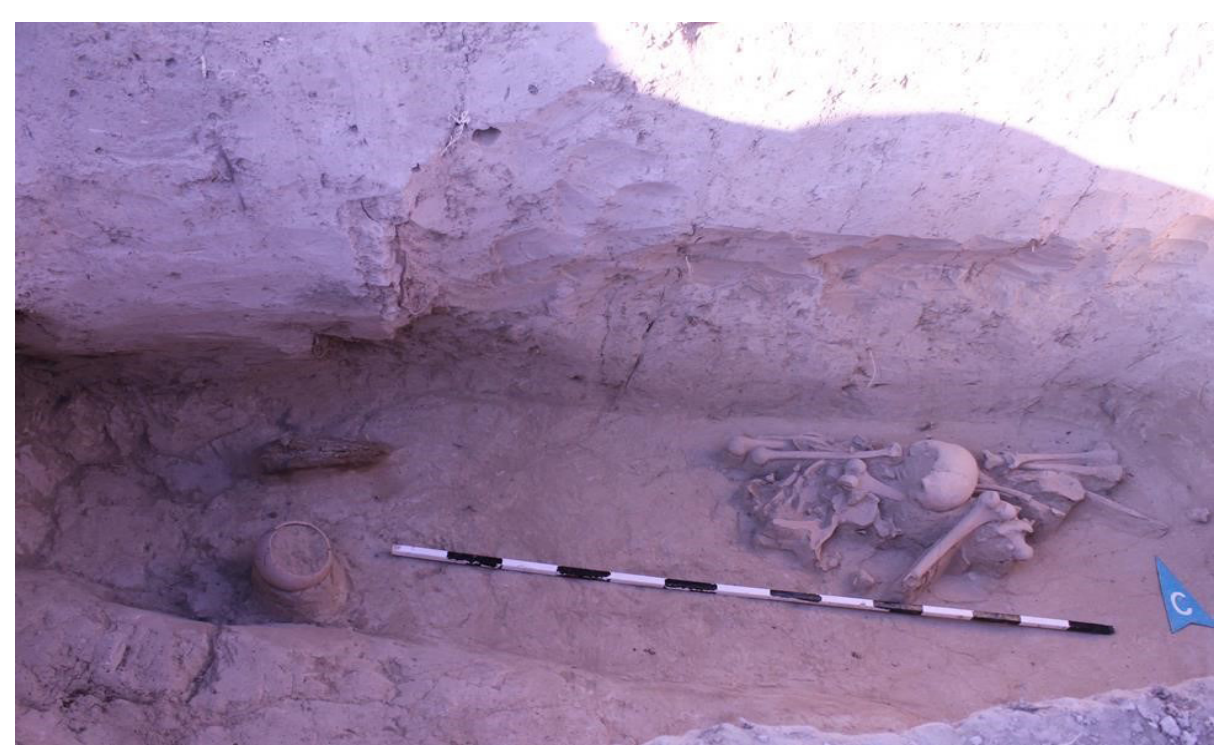

Figure 3 - Mound №1. Tomb

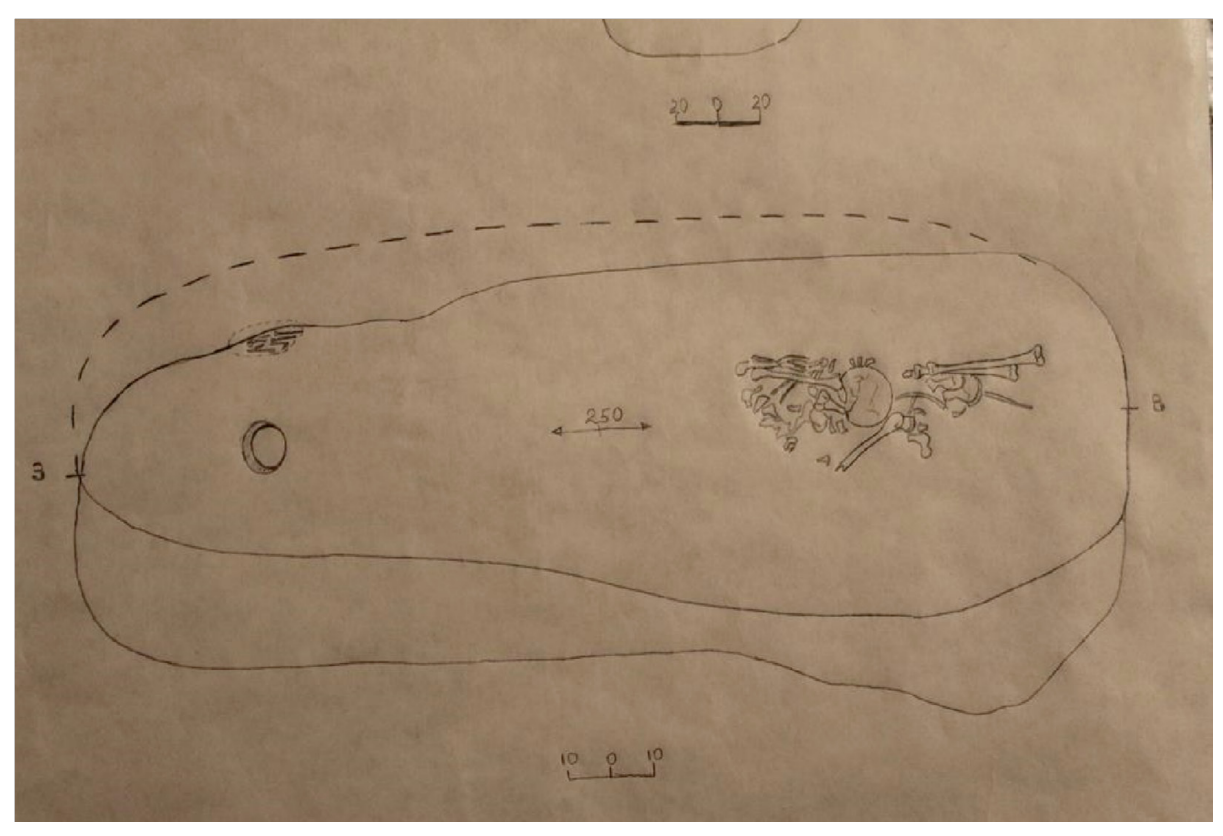

Figure 4 - Mound №1. Graphic design 


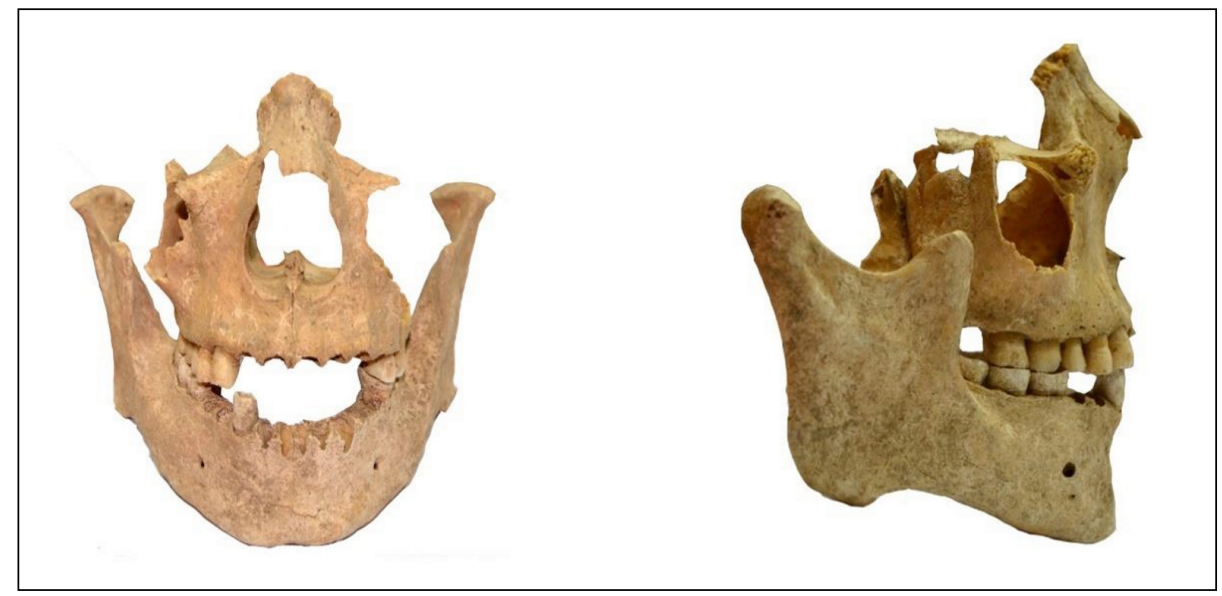

Figure 5 - Craniological features of the individual from the mound №1

Postcranial skeleton is represented by almost all strongly fragmented bones. The bones were broken, the broken places were wiped, which is probably connected with the ancient robbery of the mound.

According to the estimated grades of V.V. Bunak (Mamonova, 1986: 21-33), the branchial bone, elbow and femoral bone have a short length. The brachial and femoral bones are also characterized by large circles of diaphysis, which determines their greater strength and overall massiveness. Bones are massive.
The height was calculated on the basis of the following formulas: according to K. Pearson and A. Lee $-154.6 \mathrm{~cm}$; according to S. Dupertuis and D. Hadden $-160.6 \mathrm{~cm}$. On average height was 157.6 $\mathrm{cm}$, that is, a small one.

The mound №2

A skeleton without a skull is represented by separate bones of the postcranial skeleton of a woman aged 18 to 25 years. The traces of cribra orbitalia are fixed on the skull, which may indicate anemia.

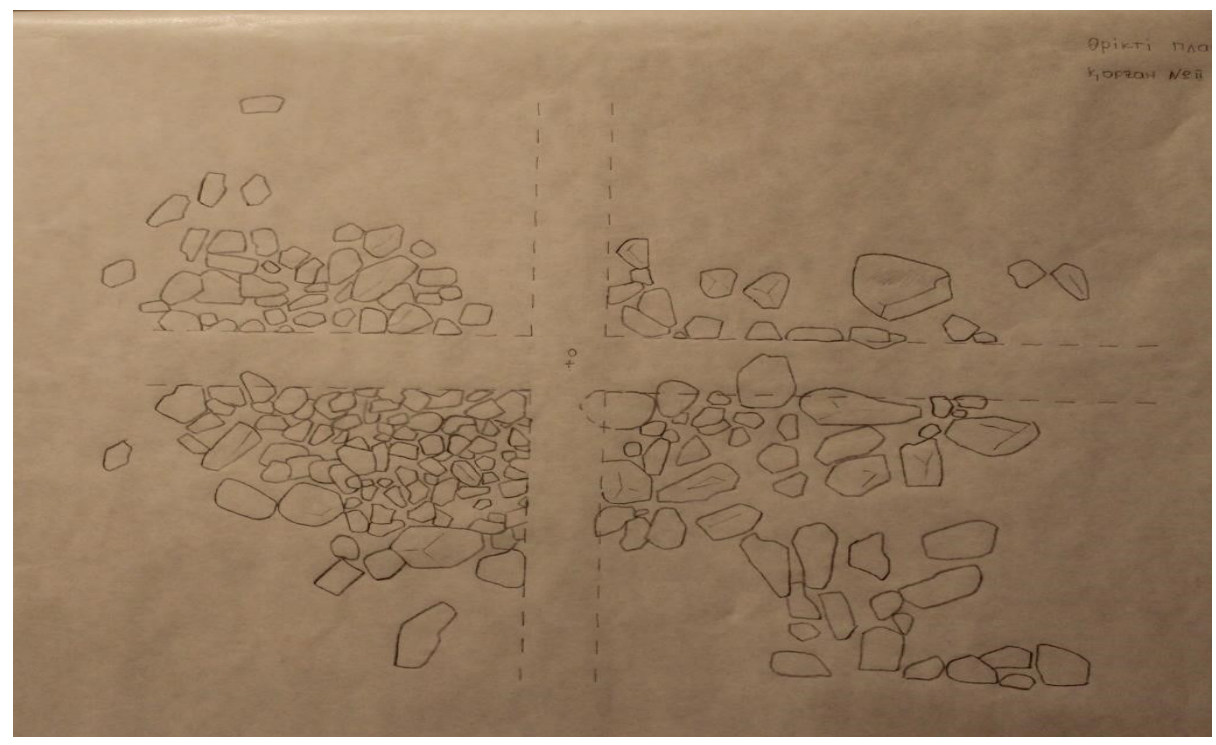

Figure 6 - Mound №2. The scheme of excavations 


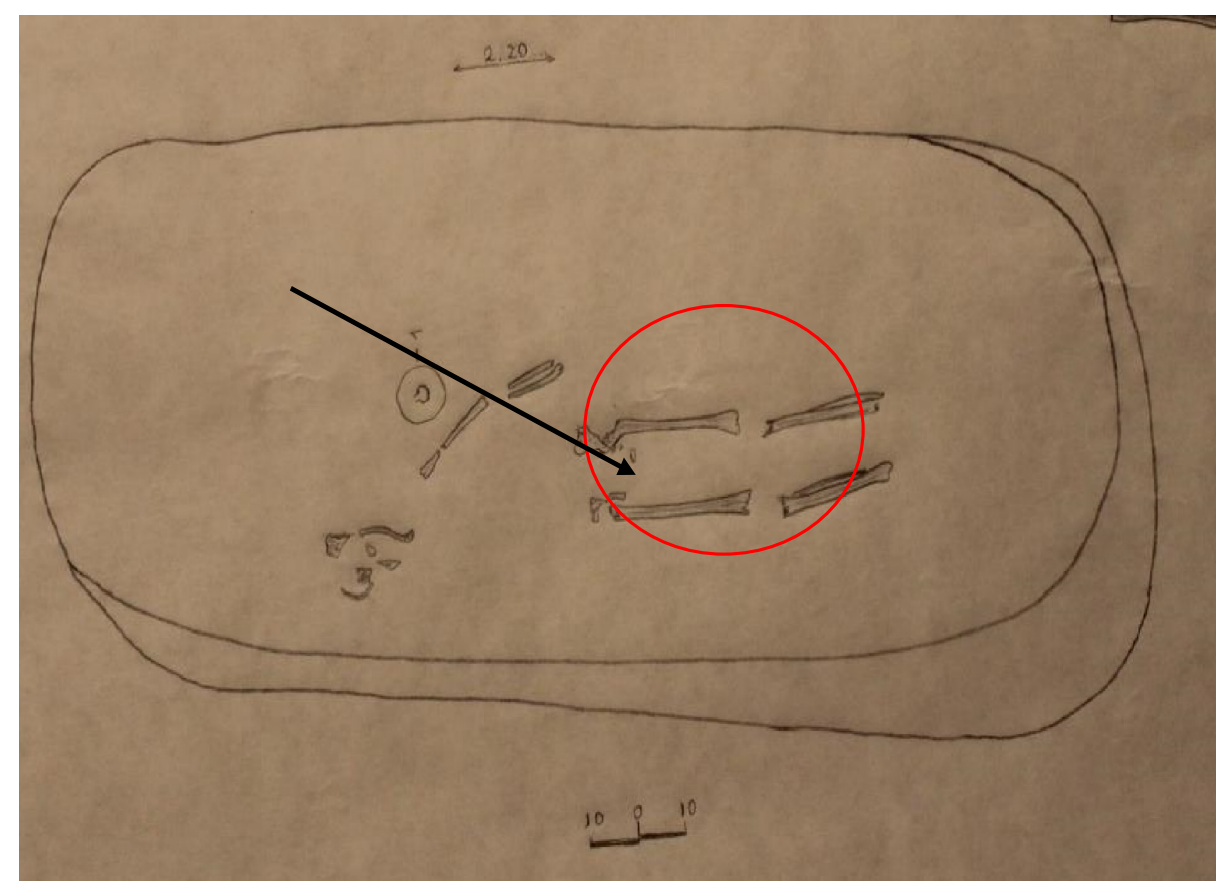

Figure 7 - Mound №2. The scheme of tomb

The mound №3

Two burials were found in the burial mound. The main (lower) is represented by the male skeleton of 35-45 years.

Lower burial. The skull is hyper dolichocranic with a combination of a long length and a very small width of the brain box. The height of the cranial vault from average po and from $b$ is small. The horizontal circle through average $g$, transverse arc po-br-po and sagittal arc are estimated by average values. The frontal bone is very narrow. The angle of the forehead from $n$ is small, the bending height of the forehead is large. The width of the base of the skull is very small.

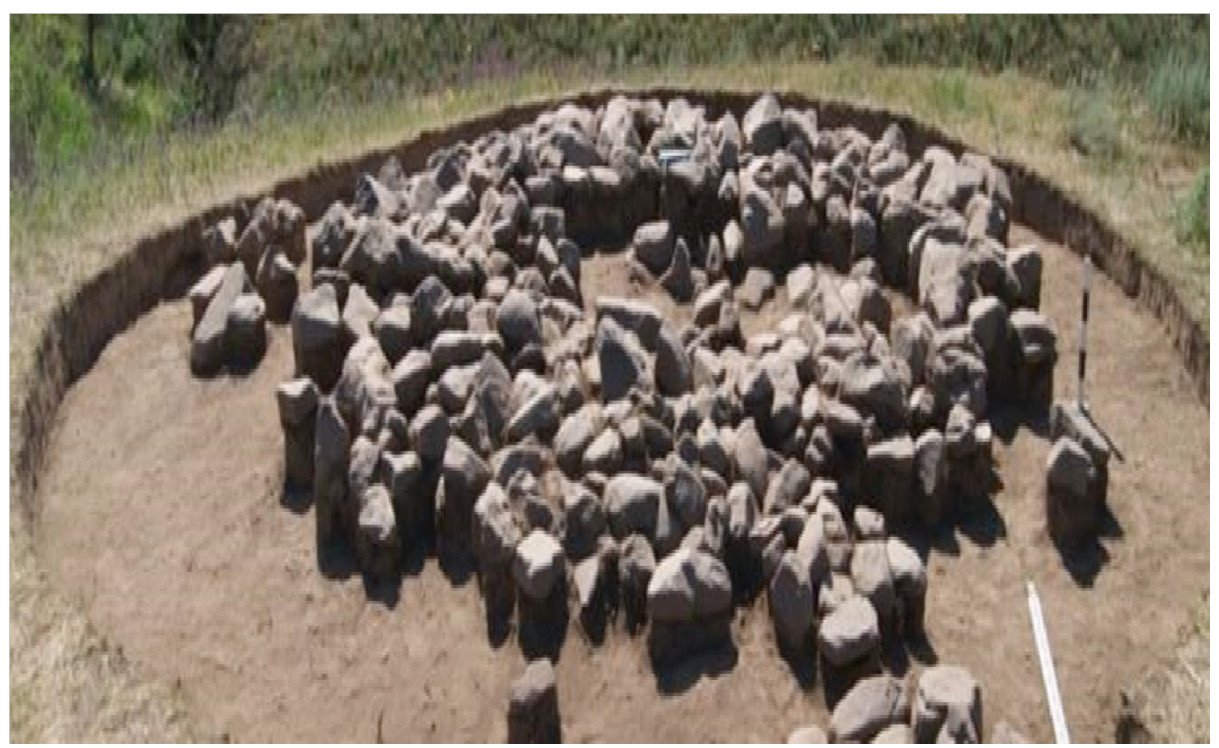

Figure 8 - Mound №3. View from the East 


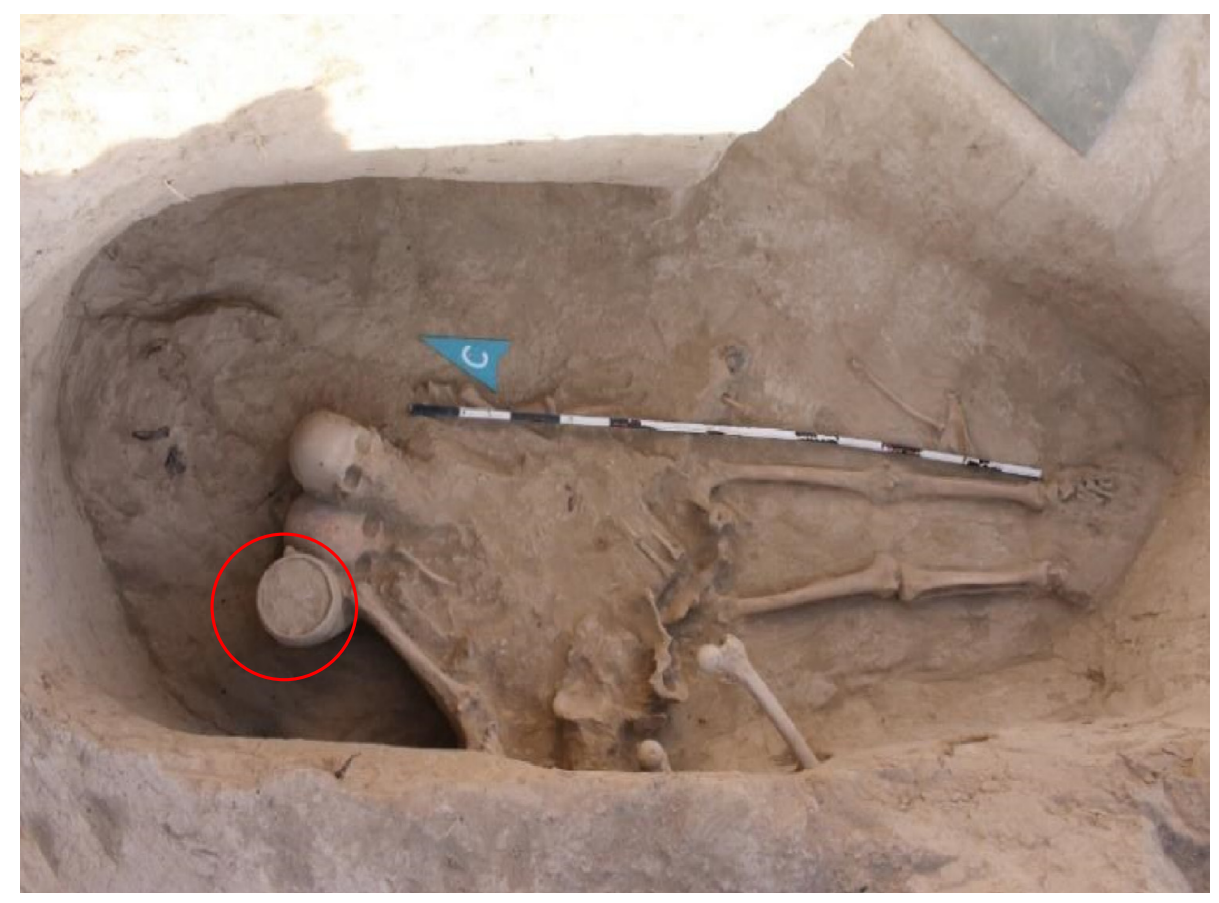

Figure 9 - Mound №3. The tomb

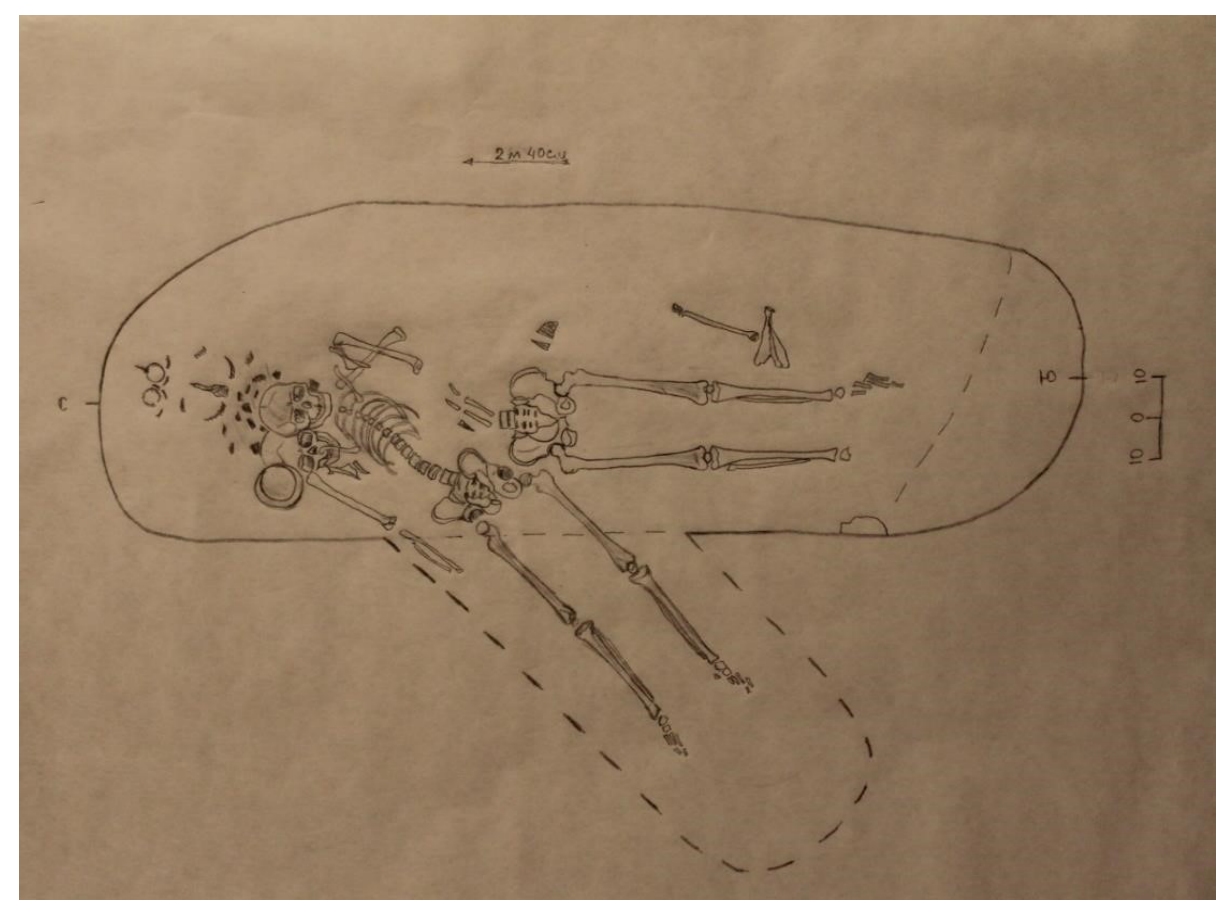

Figure 10 - Mound №3. The scheme of the tomb

The facial skeleton is medium-wide by value upper, small in average width and zygomatic diameters. Orbits are medium-wide and low, very low according to the index. Nose of platinum proportions is in low height and width. Noseband is medium upper and medium wide. In the horizontal plane, the face is clinognathic on the upper and lower levels. Canine fossa is medium deep. The lower jaw is characterized by a small condylar, a small angular and middle anterior width and an 
average thickness of the body and a very small width of the limb.

The remains of the skeleton are of a satisfactory degree of preservation from the burial place. According to estimated grades of V.V. Bunak (Mamonova, 1986), all long tubular bones are characterized by a long length. In this case, the clavicles, branchial bone, femoral and tibil bones have large values of the circumferences of the diaphyses, which cause their greater strength and massiveness. The bones of the forearm for a long length have average values of the circumferences of the diaphyses, which causes their gracilis. Diaphysis of the femoral bone in the middle part of the diaphysis is flattened in the transverse direction. In the upper part of the diaphysis of the femoral bone, asymmetry is observed in this indicator: the right femoral bone is flattened in the transverse direction, the left femoral is in the sagittal. Such asymmetry could be formed due to an uneven weight on the femoral bones in the process of their growth. Tibil bones symmetrically flattened in the sagittal direction in the upper part of the diaphysis (Gerasimov,1955).

According to the intermembranal index (73.0), the lower part of the body is considerably shortened relatively to the upper one. The forearm is elongated relatively to the shoulder, the shin is elongated relatively to the hip. The shoulder is elongated in relation to the thigh, and the forearm is elongated in relation the shin. The height was calculated on the basis of the following formulas: according to
K. Pearson and A. Lee $-169.1 \mathrm{~cm}$; according to $\mathrm{S}$. Dupertuis and D. Hadden $-174.3 \mathrm{~cm}$. The average height was $171.7 \mathrm{~cm}$, that is, a relatively high one. Pathology. Frazzle bone of the postcranial skeleton corresponds to the biological age of the individual. There are degenerative-dystrophic changes in the vertebrae, shoulder, hip and knee joints with compensatory reaction in the form of marginal bony growths (Mamonova, 1986).

Upper burial. The skull is mesocarpal, with a combination of a large length and a large width of the brain box. The height of the arch from the po is large, from the $b$ is small. The horizontal circle through $g$ is large, the transverse arch po-br-po and the sagittal arc are estimated by average values. The frontal bone is very wide. The angle of the forehead profile from $n$ is small, the bending height of the forehead is large. The width of the base of the skull is very large.

The facial skeleton is wide by value the upper, medium width and zygomatic diameter. The orbits are medium-wide and medium-high, mesophilic according to the indicator. Nose of platinum proportions is at high altitude and very large width. The transfer is low and medium wide. In the horizontal degree of the face is flattened on the upper and lower levels. Canine fossa is flattened. The lower jaw is characterized by a large condylar, angular and large front width, as well as large values of the thickness of the body and the width of the limb.

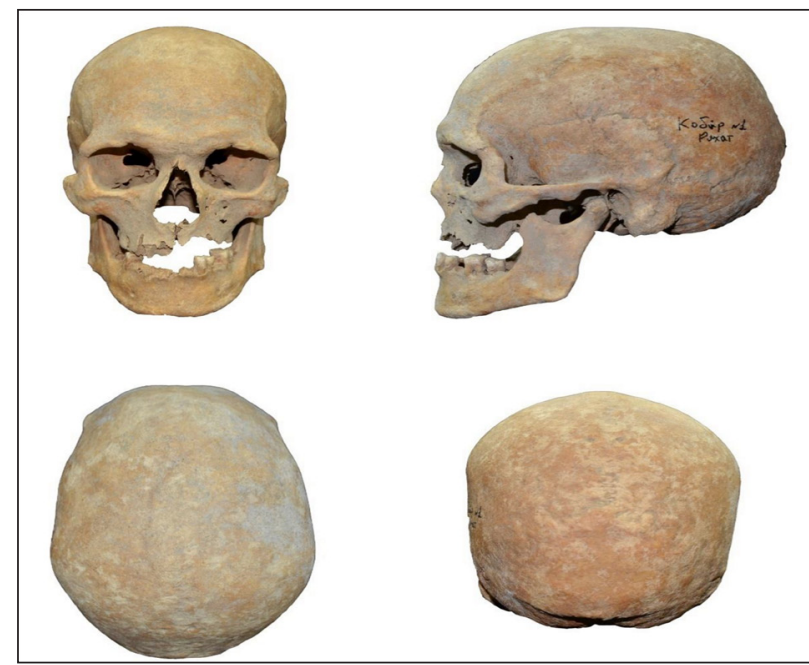

Figure 11 - Craniological features of the individual from the mound №3

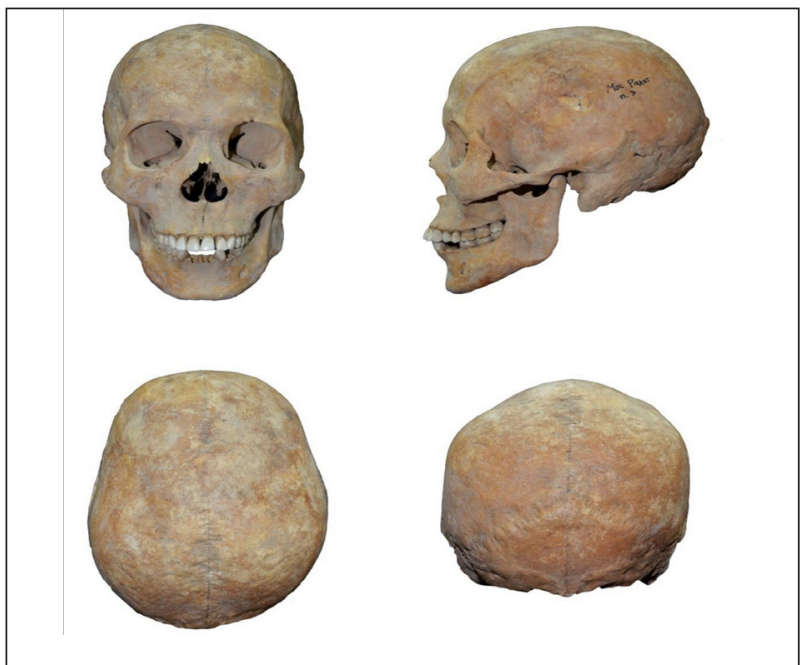

Figure 12 - Craniological features of the individual from the mound №3 
The remains of the skeleton are of a satisfactory degree of preservation from the burial place. The remains of the skeleton with bones of varying degrees of preservation are occurred in the burial place. According to estimated grades V.V. Bunak (Mamonova, 1986), all long tubular bones are characterized by a short length, with large circles of diaphyses, which determines their greater strength and overall massiveness. Bones are visually shortened and very massive.

The growth was calculated on the basis of the following formulas: according to K. Pearson and A. Lee $-153.8 \mathrm{~cm}$; according to S. Dupertuis and D. Hadden $-159.8 \mathrm{~cm}$. The average growth was 156.8 $\mathrm{cm}$, that is, a small one.

Both individuals are of different anthropological types. Lower has a characteristic, often found in the Bronze Age and less often in the early Iron Age - strongly expressed European look. The upper is clearly expressed Mongoloid face, typical of the Middle Ages. However, the anthropological characteristics can not serve as a support for dating and it is necessary to obtain radiocarbon dates, in order to more accurately determine the time of burial. The specific appearance of the buried may possibly introduce new hypotheses into the processes taking place in the given territory in the EIC, that the dates are specified. The individual from the burial mound №1 finds wide analogies (with the reservation for poor skull preservation) among the population of the region of the early Iron Age.

\section{Conclusion}

The results of the laboratory analysis and artifacts allowed determining the cultural stages of the Rakhat camp. A deeper study of the complex of monuments in the framework of the State Program "The people in the flow of history» on the theme «The Research Program of international scientific laboratory on archaeological dating of the artifacts» provides with improvement of archeological degree at the universities of the republic, modeling of paintings from ancient epochs, restoration of the lives and ecological conditions of the first people.

At the same time, the goal of archaeological research works carried out on the basis of the international scientific-research laboratory «Geoarcheology» of al-

Farabi Kazakh National University in the framework of the State Program «The people in the flow of history» on the theme "The Research Program of international scientific laboratory on archaeological dating of the artifacts» is to determine the historical significance. Most materials of the monuments, mounds, settlements and nomad camps located in the settlement Rakhat show that the region's historical roots are deep.

In the conclusion, the world's science has a great interest in the culture and art of the first community society. The success of natural sciences is widely used in the decision of a number of questions, and new technological possibilities help to consider and clarify some issues. At the same time, Kazakhstan archeologists have achieved many successes in the field of natural sciences (Paleobotanics, Paleogeology, Odontology, Chemistry and Physics, Genetics, Geomorphology, Palinology etc.). Its results are considered to be a significant success in the historiography of the world archeology.

In the future, resuming research in the settlement Rakhat is important for science. We can make a significant contribution to the history of Kazakhstan by defining the borders, cultural layers and the construction sites of the settlement. Further studying of the remains of the native culture of the vast area, provides with valuable information on the political, socio-economic situation of the settlement. Science advances in the search of time and space for tasks and questions. Its branches as natural science, engineering, mathematics, and physics increase labor productivity and rises the wealth of the nation, indirectly promoting material production in the public-humanitarian sphere, and ultimately serves to extend the nation's lives. At the same time, the duty of archeology is the most responsible. The science of archeology sheds light on the nation, brings them up and forms its patriotism, by examining the nation's discovered and lost, the existence and the loss, teachings and experience of the past years.

In the era of totalitarianism, Kazakhstan's archeology failed to fulfill any of these tasks. That's why the chance is just appeared. In short, the future of our young state is connected with science, and the future of science is closely linked to the state policy. The leadership of Kazakhstan, aware of the fact that it does not engage in this relationship, will soon come to terms with raising its knowledge and science to a qualitatively new heights. Strategy of Kazakhstan's entry into the 50 most developed countries of the world is the creation of academic centers and educational institutions that conform to the highest international standards, modern education development, continuous improvement of qualification and retraining of personnel and further development of the culture of the people of Kazakhstan. 


\section{References}

Martynov A.I. (2005). Archeology: the Textbook. 5th ed. Moskva: Higher education. Est. 447 p.

Baipakov K.M., Taymagambetov Zh.K. (2009). Kazakhstan archeology: textbook. Almaty: Kazakh university. 401p.

Nurmukhanbetov B.N., Mukhtarova G.R. (2001). Issyk-Necropolis IssykArcheological Complex Esik-Rakhat-Republican State Historical and Cultural Reserve-Museum «Issyk» // Sak culture of Saryarka in the context of studying ethno-sociocultural processes of the steppe Eurasia: abstracts of the round table discussions. Karaganda: Technology of Imaging.

Nurmukhanbetov B.N., Tulegenov T.Zh. (2012). Protection, use and museification of the Esik-Rakhat archeological complex in the zone of the Issyk reserve-museum // Materials of the republican scientific-practical conference «IV Orazbaevsky readings» on the theme «Problems and achievements of domestic archeology and ethnology in the XXI century» dedicated to the 90th anniversary of A.M. Orazbaev. Almaty: Kazakh university.

Nurmukhanbetov B.N., Akhatov, G.A. Bermagambetov A.Zh. (2005). Archaeological study in the burial ground of Esik»// Report on the Archaeological research within the state program of «Cultural heritage» in 2004. Almaty: Almaty kitap.

Buzhilova A.P. (1998). Paleopathology in bioarchaeological reconstructions // Historical ecology of man. Methodology of biological research. Moskva: 18.

Gerasimov M.M. (1955). «Restoration of the face on the skull» (Modern and Fossil Man) // Proceedings of the Institute of Ethnography of the USSR Academy of Sciences. New Ser. 28.

Mamonova N.N. (1986). Experience in the application of chat B.B.Bunak in the development of osteometric materials // Problems of the evolutionary morphology of human and his reash. Moskva. 